\title{
Effect of tramadol on lung injury induced by skeletal muscle ischemia-reperfusion: an experimental study*
}

\author{
Efeito do tramadol na lesão pulmonar induzida por isquemia-reperfusão \\ de músculo esquelético: um estudo experimental
}

\author{
Mohammad Ashrafzadeh Takhtfooladi, Amirali Jahanshahi, Amir Sotoudeh, \\ Gholamreza Jahanshahi, Hamed Ashrafzadeh Takhtfooladi, Kimia Aslani
}

\begin{abstract}
Objective: To determine whether tramadol has a protective effect against lung injury induced by skeletal muscle ischemia-reperfusion. Methods: Twenty Wistar male rats were allocated to one of two groups: ischemia-reperfusion (IR) and ischemia-reperfusion + tramadol $(\mathrm{IR}+\mathrm{T})$. The animals were anesthetized with intramuscular injections of ketamine and xylazine ( $50 \mathrm{mg} / \mathrm{kg}$ and $10 \mathrm{mg} / \mathrm{kg}$, respectively). All of the animals underwent 2-h ischemia by occlusion of the femoral artery and 24-h reperfusion. Prior to the occlusion of the femoral artery, $250 \mathrm{lU}$ heparin were administered via the jugular vein in order to prevent clotting. The rats in the $1 \mathrm{R}+\mathrm{T}$ group were treated with tramadol $(20 \mathrm{mg} / \mathrm{kg}$ i.v.) immediately before reperfusion. After the reperfusion period, the animals were euthanized with pentobarbital ( $300 \mathrm{mg} / \mathrm{kg}$ i.p.), the lungs were carefully removed, and specimens were properly prepared for histopathological and biochemical studies. Results: Myeloperoxidase activity and nitric oxide levels were significantly higher in the IR group than in the $\mathrm{IR}+\mathrm{T}$ group $(\mathrm{p}=0.001$ for both). Histological abnormalities, such as intra-alveolar edema, intra-alveolar hemorrhage, and neutrophil infiltration, were significantly more common in the IR group than in the IR+T group. Conclusions: On the basis of our histological and biochemical findings, we conclude that tramadol prevents lung tissue injury after skeletal muscle ischemia-reperfusion.
\end{abstract}

Keywords: Tramadol; Muscle, skeletal; lschemic attack, transient; lung lnjury.

\section{Resumo}

Objetivo: Investigar se o tramadol tem um efeito protetor contra a lesão pulmonar induzida por isquemia-reperfusão de músculo esquelético. Métodos: Vinte ratos Wistar machos foram divididos em dois grupos: grupo isquemiareperfusão (IR) e grupo isquemia-reperfusão + tramadol ( $1 R+T)$. Os animais foram anestesiados com cetamina e xilazina (i.m., $50 \mathrm{mg} / \mathrm{kg}$ e $10 \mathrm{mg} / \mathrm{kg}$, respectivamente). Todos os animais foram submetidos a $2 \mathrm{~h}$ de isquemia por oclusão da artéria femoral e $24 \mathrm{~h}$ de reperfusão. Antes da oclusão da artéria femoral, foram administrados 250 UI de heparina pela veia jugular para impedir a coagulação. Os ratos do grupo IR+T foram tratados com tramadol (20 $\mathrm{mg} / \mathrm{kg}$ i.v.) imediatamente antes da reperfusão. Após o periodo de reperfusão, os animais foram sacrificados com pentobarbital (300 mg/kg i.p.), os pulmões foram removidos cuidadosamente, e os espécimes foram preparados adequadamente para estudos histopatológicos e bioquímicos. Resultados: A atividade de mieloperoxidase e os níveis de óxido nítrico foram significativamente maiores no grupo IR que no grupo IR+T ( $p=0,001$ para ambos). Anormalidades histológicas, como edema intra-alveolar, hemorragia intra-alveolar e infiltração neutrofílica, foram significativamente mais frequentes no grupo $\mathrm{IR}$ que no grupo $\mathrm{IR}+\mathrm{T}$. Conclusões: Com base nos resultados histológicos e bioquímicos deste estudo, concluímos que o tramadol tem um efeito protetor contra o dano ao tecido pulmonar após isquemia-reperfusão de músculo esquelético.

Descritores: Tramadol; Músculo esquelético; Ataque isquêmico transitório; Lesão pulmonar.

\footnotetext{
*Study carried out in the Department of Veterinary Surgery, Faculty of Specialized Veterinary Science, Science and Research Branch, Islamic Azad University, Hesarak, Tehran, Iran.

Correspondence to: Mohammad Ashrafzadeh Takhtfooladi. Department of Veterinary Surgery, Faculty of Specialized Veterinary Science, Science and Research Branch, Islamic Azad University, Hesarak, Tehran, Iran.

Tel.00989121590428. E-mail: dr_ashrafzadeh@yahoo.com

Financial support: None.
}

Submitted: 5 December 2012. Accepted, after review: 14 May 2013. 


\section{Introduction}

Ischemia-reperfusion injury is one of the most common types of cell injury that occurs in a variety of surgical practices. Reperfusion of ischemic organs can result in tissue injury, which manifests as microvascular and parenchymal cell dysfunction. The mechanisms underlying ischemiareperfusion injury have been previously described; polymorphonuclear leukocytes and reactive oxygen metabolites have been indicated to have pivotal roles in the etiology. ${ }^{(1-3)}$

Skeletal muscle ischemia-reperfusion resulting from trauma, limb revascularization, orthopedic surgery, free flap reconstruction, or any other etiology not only leads to muscle damage itself but also causes injury involving a severe destruction of remote organs. Considerable advances have been made in the understanding of the mechanisms of this systemic response regarding the skeletal muscle ischemia-reperfusion sequence. Remote organs with intense microcapillary systems, such as the lungs, are prone to developing this type of systemic injury. ${ }^{(3,4)}$

Various investigators have demonstrated that the opioid pathway is involved in tissue preservation during hypoxia or ischemia, and this protection is mediated via the delta opioid receptor. ${ }^{(5,6)}$ Tramadol hydrochloride is an effective analgesic drug used for severe acute and chronic pain conditions. It has a weak affinity to the $\mu$-opioid receptor and inhibits the reuptake of monoamines in the central nervous system, thereby activating the descending inhibitory systems. ${ }^{(7,8)}$ Recent research discloses that tramadol decreases lipid peroxidation and regulates noradrenalin uptake, and, therefore, these therapeutic properties are used for the management of myocardial ischemia. ${ }^{(9)}$

The aim of the present study was to investigate the potential protective effect of tramadol hydrochloride on lung ischemia-reperfusion injury induced by the hind limb model by means of histopathological evaluation and determination of inflammatory responses via myeloperoxidase (MPO) activity and nitric oxide (NO) levels in the lung tissue of rats.

\section{Methods}

All of the animals used in the present research were properly cared in accordance with the norms of the Laboratory of Animal Experimentation at the lslamic Azad University Faculty of Specialized Veterinary
Sciences, in Tehran, Iran. The study was approved by the Animal Research Ethics Committee of the Department of Veterinary Surgery of the university.

Twenty Wistar male rats, weighing 250-300 g (12-15 weeks old), were used in the present study. All of the rats were maintained under constant room temperature and standard conditions, with ad libitum access to water and commercial food, and placed in individual plastic cages with soft bedding. The animals were divided randomly into two experimental groups of ten rats each: ischemia-reperfusion (IR) group and ischemiareperfusion + tramadol $(\mathrm{IR}+\mathrm{T})$ group. Anesthesia was induced using ketamine and xylazine (i.m., 50 $\mathrm{mg} / \mathrm{kg}$ and $10 \mathrm{mg} / \mathrm{kg}$, respectively). After induction of anesthesia, the left hind limb was completely clipped. After clipping, disinfecting, and dropping, a skin incision was made on the medial surface of the left hind limb. The femoral artery and vein were isolated from the surrounding tissues, and the femoral artery was exposed and clamped with a mini bulldog forceps. Prior to the occlusion of the femoral artery, 250 IU heparin was administered via the jugular vein in order to prevent clotting. All of the animals underwent 2-h ischemia by the occlusion femoral artery with a vascular clamp and 24-h reperfusion. The animals were maintained in dorsal recumbency and kept anesthetized throughout the duration of the ischemic period. Additional doses of the anesthetics were given as necessary in order to maintain anesthesia during the experiment. Body temperature was maintained with a heating pad under anesthesia. The animals in the $\mathrm{IR}+\mathrm{T}$ group were administered tramadol i.v. $(20 \mathrm{mg} / \mathrm{kg})^{(10)}$ immediately before reperfusion. Following the ischemic period, the vascular clamp was removed, and the surgical site was routinely closed. After the surgery, fluid losses were replaced by intraperitoneal administration of 5-mL warm isotonic saline, and the rats were returned to their cages with ad libitum access to commercial food and water during the reperfusion period. After 24 $\mathrm{h}$ of reperfusion, the rats were euthanized with an overdose of intraperitoneal pentobarbital injection (300 mg/kg), and the left lungs were harvested and fixed in 10\% formaldehyde for histopathological examination under light microscopy. The right lungs were removed and stored at $-20^{\circ} \mathrm{C}$ for analysis. The lung tissue homogenate and supernatant samples were prepared as described by Yildirim et al. ${ }^{(11)}$

The biochemical assay consisted of determining MPO activity and NO levels in lung tissue. The activity 
of $\mathrm{MPO}^{(12)}$ was analyzed spectrophotometrically as described elsewhere, whereas NO levels in lung tissue were measured by the Griess reaction..$^{(13)}$

All of the left lung tissue samples were fixed in $10 \%$ formalin solution and processed routinely (embedded in paraffin blocks, the anterior lung region being sectioned into 6 - $\mu \mathrm{m}$ sections, and stained with H\&E). The severity of lung injury was determined by a pathologist who was blinded to the experiment. Lung injury was classified into four levels, as follows: level 0, no diagnostic change; level 1, mild neutrophil leukocyte infiltration and mild to moderate interstitial congestion; level 2, moderate neutrophil leukocyte infiltration, perivascular edema formation, and partial destruction of pulmonary architecture; and level 3, dense neutrophil leukocyte infiltration and complete destruction of pulmonary structure. ${ }^{(14)} \mathrm{A}$ total of four slides from each lung sample were randomly screened, and the mean level was considered representative of the sample.

Statistical analyses were carried out with the Statistical Package for the Social Sciences, version 11.2 (SPSS Inc., Chicago, IL, USA). The distribution of the groups was analyzed with one-sample Kolmogorov-Smirnov test. Biochemical results showed normal distribution, and one-way ANOVA was used. Histopathological results were analyzed using Kruskal-Wallis and Mann-Whitney $\mathrm{U}$ tests. Values of $p<0.05$ were considered as statistically significant.

\section{Results}

All of the rats survived until the end of the study period.

Regarding biochemical results, NO levels were significantly higher in the lungs of the rats in the IR group than in those of the rats in the $1 R+T$ group $(p=0.001$; Figure 1). Likewise, MPO activity, a novel indicator for neutrophil function, was significantly higher in the IR group than in the $1 R+T$ group ( $p=0.001$; Figure 2 ).

Figure 3 illustrates a representative photomicrograph of lung tissue of the rats in the IR group $24 \mathrm{~h}$ after reperfusion. Histological changes in the $\mathrm{IR}$ group included intra-alveolar edema, intra-alveolar hemorrhage, and neutrophil infiltration. The mean level of lung injury in the IR group was $2.10 \pm 0.89$. These pathological changes, particularly neutrophil infiltration, were much less common in the $\mathrm{IR}+\mathrm{T}$ group (Figure 4). One animal in the $\mathrm{IR}+\mathrm{T}$ group presented no injury, whereas the level of lung injury in the other animals ranged from 1 to 2 (mean, 1.70 \pm 0.23 ). Histopathologically, there was a significant difference between two groups ( $p=0.035)$.

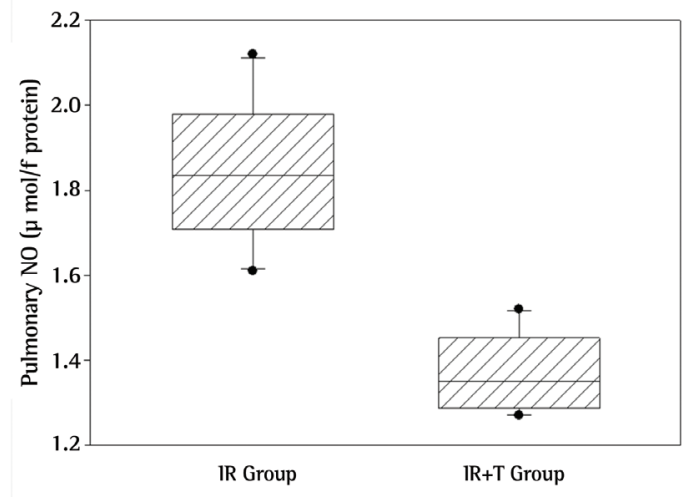

Figure $\mathbf{1}$ - Levels of nitric oxide (NO) in lung tissue between the groups studied $(p=0.001)$.

$\mathrm{IR}$ : ischemia-reperfusion; and IR+T: ischemia-reperfusion + tramadol.

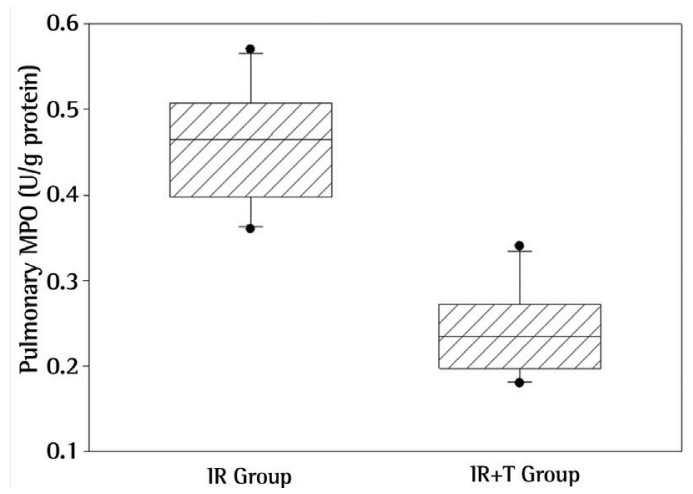

Figure 2 - Myeloperoxidase (MPO) activity in lung tissue between the groups studied $(p=0.001)$. IR: ischemia-reperfusion; and IR+T: ischemia-reperfusion + tramadol.

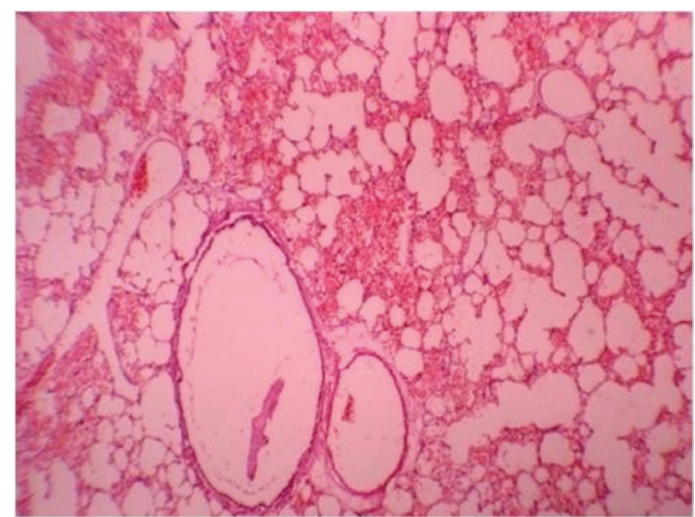

Figure 3 - Photomicrograph under light microscopy. lung tissue of a rat in the ischemia-reperfusion group showing extensive intra-alveolar hemorrhage (H\&E; magnification, $\times 40$ ). 


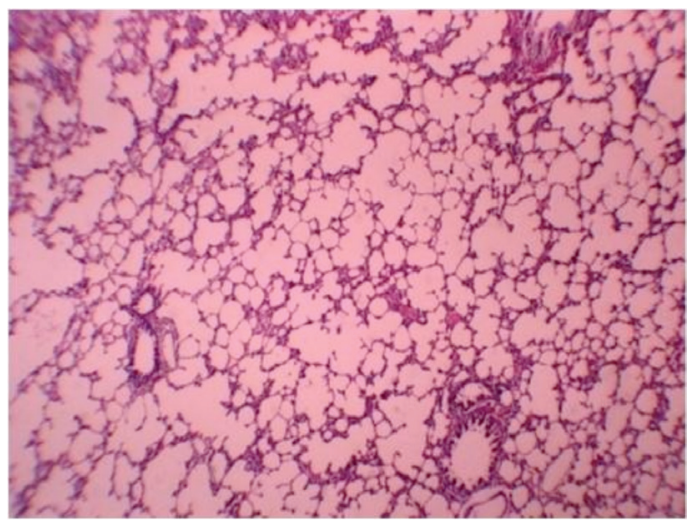

Figure 4 - Photomicrograph under light microscopy. lung tissue of a rat in the ischemia-reperfusion + tramadol group showing fewer histological changes and better preserved, practically normal structures (HctE; magnification, $\times 40$ ).

\section{Discussion}

The lung is one of the most important target organs in multiple organ dysfunction syndrome or multiple system organ failure caused by severe injury. Lungs can be damaged by indirect injuries caused by the intestine, liver, and skeletal muscle reperfusion, as well as by circulatory shock..$^{(15,16)}$ The mechanism of respiratory failure after ischemiareperfusion injury is a complex process which is associated with the activation of systemic inflammatory mediators, including bacteriotoxins, immunocytokines, and inflammatory mediators, such as TNF and interleukins. ${ }^{(17,18)}$ TNF and NO are significant determinants of the lung injury process, which is caused by lower extremity ischemia-reperfusion, ${ }^{(19,20)}$ whereas MPO is an index for the accumulation of activated leukocytes in tissues and is associated with an overproduction of reactive oxygen species (ROS); therefore, leukocyte accumulation, high MPO activity, and excessive ROS production exist together in the inflammatory process. Overproduction of ROS results in a quick depletion of antioxidant capacity of the body, which consequently leads to the damage of target organs. ${ }^{(21,22)}$

Animal studies showed that opioids can act as a trigger for both phases of ischemic preconditioning, ${ }^{(23)}$ and serotonin augments ${ }^{(24)}$ or attenuates ${ }^{(25)}$ this phenomenon depending on the concentration. Mayfield et al. ${ }^{(6)}$ and Chien et al..$^{(5)}$ have demonstrated that the opioid pathway is involved in tissue preservation during hypoxia or ischemia. It has been proven that morphine has cardioprotective effects during ischemia-reperfusion. ${ }^{(26,27)}$ Factors such as respiratory depression and histamine release are the disadvantages of morphine usage during the postoperative period. ${ }^{(28)}$ Tramadol is a centrally acting analgesic drug with negligible respiratory depressant action, very low tolerance, and physical dependence liability. The use of tramadol (10 and $20 \mathrm{mg} / \mathrm{kg}$ ) showed a protective effect against transient forebrain ischemia in rats. ${ }^{(10)}$ In the present study, we tested the hypothesis that $20 \mathrm{mg} / \mathrm{kg}$ of tramadol could protect the lungs from remote organ injury after skeletal muscle ischemia-reperfusion. Higher doses of tramadol should be investigated in order to determine whether higher doses would have a higher protective effect.

The present study, in concert with previous ones, ${ }^{(29-31)}$ confirmed that lower limb ischemiareperfusion could induce acute lung injury in rats. We demonstrated that the acute lung injury induced by lower limb ischemia-reperfusion could be mitigated by tramadol. Our data demonstrate that tramadol significantly decreases the severity of acute lung injury, the infiltration of macrophages and polymorphonuclear leukocytes in the lungs, pulmonary vascular permeability, and intra-alveolar hemorrhage, as well as inhibiting cellular apoptosis in the lungs after skeletal muscle ischemiareperfusion injury. These results suggest the possibility of clinical application of tramadol in ischemia-reperfusion injury of the lung. Different dosages, alternative time protocols, and forms of tramadol administration for lung injury induced by skeletal muscle ischemia-reperfusion should be investigated in future studies.

\section{References}

1. Zimmerman BJ, Granger DN. Mechanisms of reperfusion injury. Am J Med Sci. 1994;307(4):284-92. http://dx.doi. org/10.1097/00000441-199404000-00009

2. Atahan E, Ergun Y, Belge Kurutas E, Cetinus E, Guney Ergun U. lschemia-reperfusion injury in rat skeletal muscle is attenuated by zinc aspartate. J Surg Res. 2007;137(1):109-16. http://dx.doi.org/10.1016/j. jss.2006.05.036 PMid:17112542

3. Welbourn CR, Goldman G, Paterson IS, Valeri CR, Shepro D, Hechtman HB. Pathophysiology of ischaemia reperfusion injury: central role of the neutrophil. $\mathrm{Br}$ J Surg. 1991;78(6):651-5. http://dx.doi.org/10.1002/ bjs. 1800780607 PMid:2070226

4. Schoenberg MH, Beger HG. Reperfusion injury after intestinal ischemia. Crit Care Med. 1993;21(9):1376-86. http://dx.doi.org/10.1097/00003246-199309000-00023 
5. Chien S, Oeltgen PR, Diana JN, Salley RK, Su TP. Extension of tissue survival time in multiorgan block preparation with a delta opioid DADLE ([D-Ala2, D-Leu5]-enkephalin). J Thorac Cardiovasc Surg. 1994;107(3):964-7. PMid:8127138

6. Mayfield KP, D'Alecy LG. Delta-1 opioid receptor dependence of acute hypoxic adaptation. J Pharmacol Exp Ther. 1994;268(1):74-7. PMid:8301596

7. Raffa RB, Friderichs E, Reimann W, Shank RP, Codd EE, Vaught JL. Opioid and nonopioid components independently contribute to the mechanism of action of tramadol, an 'atypical' opioid analgesic. J Pharmacol Exp Ther. 1992;260(1):275-85. PMid:1309873

8. Driessen B, Reimann W, Giertz H. Effects of the central analgesic tramadol on the uptake and release of noradrenaline and dopamine in vitro. Br J Pharmacol. 1993;108(3):80611. http://dx.doi.org/10.1111/j.1476-5381.1993.tb12882.x PMid:8467366 PMCid:1908052

9. Bilir A, Erkasap N, Koken T, Gulec S, Kaygisiz Z, Tanriverdi B, et al. Effects of tramadol on myocardial ischemia-reperfusion injury. Scand Cardiovasc J. 2007;41(4):242-7. http://dx.doi. org/10.1080/14017430701227747 PMid:17680512

10. Nagakannan P, Shivasharan BD, Thippeswamy BS, Veerapur VP. Effect of tramadol on behavioral alterations and lipid peroxidation after transient forebrain ischemia in rats. Toxicol Mech Methods. 2012;22(9):674-8. http://dx.doi. org/10.3109/15376516.2012.716092 PMid:22871232

11. Yildirim Z, Kotuk M, Erdogan H, Iraz M, Yagmurca M, Kuku l, et al. Preventive effect of melatonin on bleomycininduced lung fibrosis in rats. J Pineal Res. 2006;40(1):27-33. http://dx.doi.org/10.1111/j.1600-079X.2005.00272.x PMid:16313495

12. Wei H, Frenkel K. Relationship of oxidative events and DNA oxidation in SENCAR mice to in vivo promoting activity of phorbol ester-type tumor promoters. Carcinogenesis. 1993;14(6):1195-201. http://dx.doi.org/10.1093/ carcin/14.6.1195

13. Cortas NK, Wakid NW. Determination of inorganic nitrate in serum and urine by a kinetic cadmium-reduction method. Clin Chem. 1990;36(8 Pt 1):1440-3. PMid:2387039

14. Koksel O, Yildirim C, Cinel L, Tamer L, Ozdulger A, Bastürk M, et al. Inhibition of poly(ADP-ribose) polymerase attenuates lung tissue damage after hind limb ischemia-reperfusion in rats. Pharmacol Res. 2005;51(5):453-62. http://dx.doi. org/10.1016/j.phrs.2004.11.007 PMid:15749460

15. Rotstein OD. Pathogenesis of multiple organ dysfunction syndrome: gut origin, protection, and decontamination. Surg Infect (Larchmt). 2000;1(3):217-23; discussion 223-5. http://dx.doi.org/10.1089/109629600750018141 PMid: 12594892

16. Zhou JL, Zhu XG, ling T, Zhang JQ, Chang JY. Effect of endogenous carbon monoxide on oxidant-mediated multiple organ injury following limb ischemia-reperfusion in rats [Article in Chinese]. Zhongguo Xiu Fu Chong Jian Wai Ke Za Zhi. 2002;16(4):273-6. PMid:12181797

17. Ishii H, Ishibashi M, Takayama M, Nishida T, Yoshida M. The role of cytokine-induced neutrophil chemoattractant-1 in neutrophil-mediated remote lung injury after intestinal ischaemia/reperfusion in rats. Respirology. 2000;5(4):32531. PMid: 11192542

18. Souza DG, Cassali GD, Poole S, Teixeira MM. Effects of inhibition of PDE4 and TNF-alpha on local and remote injuries following ischaemia and reperfusion injury. $\mathrm{Br} \mathrm{J}$ Pharmacol. 2001;134(5):985-94. http://dx.doi.org/10.1038/ sj.bjp.0704336 PMid:11682446 PMCid:1573029
19. Welbourn R, Goldman G, O'Riordain M, Lindsay TF, Paterson 1S, Kobzik L, et al. Role for tumor necrosis factor as mediator of lung injury following lower torso ischemia. J Appl Physiol. 1991;70(6):2645-9. PMid:1885460

20. Tassiopoulos AK, Carlin RE, Gao Y, Pedoto A, Finck CM, Landas SK, et al. Role of nitric oxide and tumor necrosis factor on lung injury caused by ischemia/reperfusion of the lower extremities. J Vasc Surg. 1997;26(4):647-56. http://dx.doi.org/10.1016/S0741-5214(97)70065-X

21. Crinnion JN, Homer-Vanniasinkam S, Gough MJ. Skeletal muscle reperfusion injury: pathophysiology and clinical considerations. Cardiovasc Surg. 1993;1(4):317-24. PMid:8076053

22. Carden DL, Granger DN. Pathophysiology of ischaemiareperfusion injury. J Pathol. 2000;190(3):255-66. http:// dx.doi.org/10.1002/(SICI)1096-9896(200002)190:3 $<255$ ::AID-PATH526>3.0.C0;2-6

23. Fryer RM, Hsu AK, Eells JT, Nagase H, Gross GJ. Opioidinduced second window of cardioprotection: potential role of mitochondrial KATP channels. Circ Res. 1999;84(7):846-51. http://dx.doi.org/10.1161/01.RES.84.7.846 PMid:10205153

24. Nebigil CG, Etienne N, Messaddeq N, Maroteaux L. Serotonin is a novel survival factor of cardiomyocytes: mitochondria as a target of 5-HT2B receptor signaling. FASEB J. 2003;17(10):1373-5. PMid:12738797

25. Bianchi P, Pimentel DR, Murphy MP, Colucci WS, Parini A. A new hypertrophic mechanism of serotonin in cardiac myocytes: receptor-independent ROS generation. FASEB J. 2005;19(6):641-3. PMid:15703274

26. Groban L, Vernon JC, Butterworth J. Intrathecal morphine reduces infarct size in a rat model of ischemiareperfusion injury. Anesth Analg. 2004;98(4):903-9. http://dx.doi.org/10.1213/01.ANE.0000105878.96434.05 PMid:15041570

27. McPherson BC, Yao Z. Signal transduction of opioidinduced cardioprotection in ischemia-reperfusion. Anesthesiology. 2001;94(6):1082-8. http://dx.doi. org/10.1097/00000542-200106000-00024

28. Ellmauer S, Dick W, Otto S, Müller H. Different opioids in patients at cardiovascular risk. Comparison of central and peripheral hemodynamic adverse effects [Article in German]. Anaesthesist. 1994;43(11):743-9. http://dx.doi. org/10.1007/s001010050117 PMid:7840403

29. Yassin MM, Barros D'Sa AA, Parks G, Abdulkadir AS, Halliday 1, Rowlands BJ. Mortality following lower limb ischemia-reperfusion: a systemic inflammatory response? World J Surg. 1996;20(8):961-6; discussion 966-7. http:// dx.doi.org/10.1007/s002689900144 PMid:8798348

30. Yassin MM, Harkin DW, Barros D'Sa AA, Halliday Ml, Rowlands BJ. Lower limb ischemia-reperfusion injury triggers a systemic inflammatory response and multiple organ dysfunction. World J Surg. 2002;26(1):115-21. http:// dx.doi.org/10.1007/s00268-001-0169-2 PMid:11898044

31. Sirmali M, Uz E, Sirmali R, Kilbaş A, Yilmaz HR, Ağaçkiran $Y$, et al. The effects of erdosteine on lung injury induced by the ischemia-reperfusion of the hind-limbs in rats. J Surg Res. 2008;145(2):303-7. http://dx.doi.org/10.1016/j. jss.2007.02.027 PMid:17574582 
Effect of tramadol on lung injury induced by skeletal muscle ischemia-reperfusion: an experimental study

\section{About the authors}

\section{Mohammad Ashrafzadeh Takhtfooladi}

Doctoral Fellow. Department of Veterinary Surgery, Faculty of Specialized Veterinary Science, Science and Research Branch, Islamic Azad University, Tehran, Iran.

\section{Amirali Jahanshahi}

Doctoral Fellow. Department of Veterinary Surgery, Faculty of Specialized Veterinary Science, Science and Research Branch, Islamic Azad University, Tehran, Iran.

\section{Amir Sotoudeh}

Assistant Professor. Faculty of Veterinary Science, Kahnooj Branch, 1slamic Azad University, Kerman, Iran.

\section{Gholamreza Jahanshahi}

Associate Professor. Department of Oral \& Maxillofacial Pathology, School of Dentistry, Isfahan University of Medical Sciences, lsfahan, Iran.

\section{Hamed Ashrafzadeh Takhtfooladi}

Graduate Student. Faculty of Veterinary Science, Karaj Branch, lslamic Azad University, Alborz, Iran.

\section{Kimia Aslani}

Graduate Student. Faculty of Veterinary Science, Science and Research Branch, 1slamic Azad University, Tehran, Iran. 